\title{
PEMASARAN TERINTEGRASI UNTUK MENINGKATKAN MINAT MASYARAKAT DALAM MENABUNG DI BANK SYARIAH
}

\author{
Y. Rahmat Akbar 1), Mohd. Ario Wahdi Elsye 2) \\ 1)Sekolah Tinggi Ilmu Ekonomi Persada Bunda \\ 2)Universitas Muhammadiyah Riau \\ Email :yrahmat.akbar@stiepersadabunda.ac.id
}

\begin{abstract}
ABSTRAK
Penelitian ini bertujuan untuk menganalisis pengaruh pemasaran terintegrasi terhadap minat menabung pada perbankan syariah yang ada di Pekanbaru. Penelitian dilakukan secara kuantitatif dengan desain riset kausal dan deskriptif. Jumlah sampel sebesar 210 responden yang memiliki rekening tabungan pada bank syariah Pekanbaru. Teknik pengumpulan data dan teknik pengambilan sampel yang digunakan dalam penelitian ini dengan menggunakan survey dan metode purposive sampling. Teknik analisis data menggunakan Structural Equation Modeling (SEM) dengan aplikasi AMOS. Hasil penelitian memperlihatkan bahwa seluruh dimensi pemasaran terintegrasi memiliki pengaruh parsial yang positif dan signifikan terhadap minat menabung nasabah.
\end{abstract}

Kata kunci : SIVA, Pemasaran Terintegrasi, Minat

\section{PENDAHULUAN}

Dewasa ini banyak perusahaan memiliki fokus pada pelanggan dan berorientasi pasar. Ini berarti bahwa perusahaan lebih memfokuskan kegiatan dan produk pada apa yang menjadi tuntutan konsumen. Oleh karena itu, ada tiga cara yang perlu bagi perusahaan untuk melakukan hal ini yaitu pendekatan berorientasi pelanggan, rasa mengidentifikasi perubahan pasar dan pendekatan inovasi produk (Kotler \& Keller, 2012).

Dalam pendekatan customer-driven, pengendali dari seluruh keputusan pemasaran strategis adalah apa yang diinginkan konsumen. Tidak ada strategi yang dibuat sebelum lolos uji penelitian konsumen terlebih dahulu sampai segala keperuan dari konsumen tersebut telah memuaskan mereka. Setiap aspek dari penawaran pasar, termasuk sifat dari produk itu sendiri, didorong oleh kebutuhan konsumen potensial. Titik awalnya adalah selalu konsumen. Dasar pemikiran untuk pendekatan ini karena banyak produk yang mengalami kegagalan komersial meskipun menjadi terobosan teknologi, sedangkan produk tersebut tidak dapat memenuhi apa kebutuhan konsumen yang ditawarkan melalui solusi.

Pandangan rantai pasokan pada sebuah perusahaan melihat pasar sebagai titik tujuan dan sampai pada pandangan linier tentang aliran. Meskipun demikian, mula-mula perusahaan harus memikirkan pasar sasaran, kemudian merancang rantai pasokan kembali ke belakang dari titik itu. Pandangan ini disebut perencanaan rantai permintaan (demand chain planning). Pendekatan manajemen rantai permintaan tidak hanya mendorong segalanya melalui sistem. Pendekatan ini menekankan solusi yang dicari konsumen, bukan produk yang berusaha kita jual kepada mereka. Sehingga "4P" pemasaran tradisional digantikan oleh singkatan baru, yaitu SIVA, yang merupakan kependekan dari solusi, informasi, nilai (value), dan akses (Dev \& Schultz, 2005). 
Sebuah perspektif baru yang disebut dengan SIVA mampu menciptakan competitive advantage dalam industri sehingga meningkatkan eksistensi perusahaan di dalam persaingan (Srivastava \& Ho, 2006). Tak terkecuali pada industri perbankan yang merupakan perusahaan jasa. Pemasaran jasa memiliki kaitan erat dengan konsumen. Hal ini dikarenakan jasa yang memiliki karakteristik berbeda dengan produk barang (Zeithaml \& Bitner, 2000). Pada perusahaan perbankan, produk yang dijual tidak akan dapat dirasakan kualitasnya sebelum nasabah merasakannya secara langsung. Jadi, setelah nasabah memutuskan untuk membeli jasa atau produk dari bank tersebut maka baru dapat dirasakan manfaatnya.

Oleh karenanya, bank-bank melakukan berbagai terobosan pemasaran dalam menjaring nasabahnya. Mainstream ekonomi syariah yang bertumpu pada filosofi religiusitas dan digerakkan sistem bagi hasil serta orientasi maslahah dan kehalalan telah mendorong munculnya institusi perbankan syariah di tengah-tengah arus perbankan yang bertumpu pada bunga (Antonio, 2007). Untuk mengantisipasi persaingan, bank syariah sebagai suatu organisasi dituntut kemampuannya untuk selalu senantiasa berorientasi kepada pasar dengan menyesuaikan perkembangan ilmu pengetahuan dan teknologi lebih cepat dan lebih baik dari para pesaingnya disamping menjalankan bisnis secara syariah.

Persaingan bank ini tidak saja berupa perebutan nasabah kredit atau pembiayaan, tetapi juga nasabah penabung dan pengguna jasa bank lainnya. Setiap bank akan berupaya untuk memenangkan persaingan tersebut, karena bila tidak kelestarian hidup bank itu pasti tidak akan menentu. Sehingga diperlukan sebuah strategi integrated marketing agar dapat bersaing dengan kompetitor yang ada. Sebuah strategi pemasaran yang terintegrasi (integrated marketing) terbukti telah memunculkan perasaan tertarik pada calon konsumen, sehingga membentuk minat calon konsumen untuk memiliki produk sebelum memutuskan untuk melakukan pembelian secara aktual (Agustin, Kumadji, \& Yulianto, 2015).

Beragam produk yang ditawarkan beserta segala keunggulannya dan berbagai teknologi yang dimilikinya membuat masyarakat memiliki banyak alternatif pembanding bank mana dan produk yang akan dipilihnya. Bank-bank mencoba memberikan yang terbaik kepada para nasabahnya melalui penggunaan teknologi dan fasilitas layanan perbankan sebagai solusi bagi nasabah dalam memenuhi kebutuhan bertransaksi. Saat penciptaan nilai serta manfaat yang diberikan melalui inovasi produk yang semakin baik, maka konsumen akan merasa pengorbanan yang dikeluarkan akan sesuai dengan manfaan yang diterima sehingga ada rasa kepuasan yang tercapai membuat konsumen ingin terus menggunakan produk tersebut (Situmorang \& Ferdinand, 2017).

Beragam media informasi tidak luput dari pesan yang disampaikan oleh bank syariah kepada calon nasabahnya. Mulai dari televisi, radio, media sosial dan internet sampai media offline seperti koran dan majalah. Informasi yang diberikan oleh bank syariah melalui media ini membuat perusahaan memiliki banyak nasabah dan bisa bertahan sampai sekarang. Selain promosi melalui iklan dan barang-barang promosi, bank syariah juga meningkatkan pemahaman karyawannya terhadap produk-produk tabungannya dengan melakukan training, teleconference untuk peluncuran produk baru, serta brosur dan modul-modul pendukung, agar seluruh karyawan dapat memahami produk sehingga dapat memasarkan produk tabungan Bank Syariah.

Dari sisi value, bank syariah tidak menggunakan suku bunga sebagai manfaat yang diperoleh nasabahnya. Bank syariah menggunakan sistem profit and loss sharing atau bagi hasil. Dalam menghadapi persaingan bank di sisi harga ini, tidak hanya pemberian suku 
bunga pada bank konvensional atau bagi hasil pada bank syariah, tapi bank-bank juga membebaskan biaya atas transaksi perbankan nasabah seperti biaya administrasi bulanan, biaya ATM, tarik tunai gratis di seluruh ATM mana saja, dan lain sebagainya.

Semakin tumbuh dan berkembangnya perbankan di kota Pekanbaru dengan banyaknya bank yang beroperasi memudahkan masyarakat untuk memilih bank mana yang akan dipilih dan dipercaya untuk mengelola keluar masuknya uang masyarakat tersebut. Kemudahan akses lokasi kantor maupun ATM, membuat sebuah bank harus mampu membangun kinerja kantor dengan sebaik-baiknya. Jumlah kantor dan posisi/letak kantor yang strategis serta mudah dijangkau oleh berbagai alat transportasi ikut mempengaruhi keinginan nasabah untuk melakukan transaksi di bank tersebut. Dengan memberikan solusi, informasi, nilai dan akses yang baik akan membuat nasabah nyaman dan mendapat kemudahan sehingga memperlancar aktivitasnya (Ningwulan, Widyastuti, \& Derriawan, 2017), sehingga diharapkan dapat meningkatkan performance tabungan bank syariah.

Meskipun demikian, bank syariah selalu berupaya memperbaiki hal tersebut agar dapat meraih nasabah baru. Laju pertumbuhan industri perbankan syariah masih menunjukkan tren positif di tengah gempuran industri perbankan konvensional. Namun pangsa pasar dari perbankan syariah di tingkat nasional tidak lebih dari 5 persen dari total market perbankan secara umum (Yusri, 2017). Fenomena perbankan syariah secara nasional, juga menjadi masalah yang sama pada Bank Syariah di Pekanbaru. Padahal peluang pasar seharusnya lebih luas karena mayoritas penduduknya beragama Islam.

Jumlah nasabah tabungan pada Bank Syariah di Pekanbaru selalu meningkat setiap tahunnya. Sedangkan pertumbuhan jumlah outstanding tabungan mengalami fluktuatif tidak seiring dengan pertumbuhan nasabahnya. Seharusnya apabila suatu perusahaan suistanable dan terus berkembang maka hal itu akan tercermin pada peningkatan aset perusahaan setiap tahunnya. Peningkatan aset suatu bank, salah satunya juga berasal dari peningkatan jumlah outstanding tabungannya.

Di sisi lain jika dilihat potensi perkembangan pasar tabungan di Pekanbaru, market share tabungan Bank Syariah di Pekanbaru terhadap perbankan pekanbaru periode 2015 sampai dengan 2018 masih relatif rendah. Ini berarti market share tabungan Bank Syariah di Pekanbaru masih rendah dibandingkan perkembangan tabungan di perbankan Pekanbaru. Ini menjadi tantangan serius bagi perbankan syariah untuk menggarap potensi yang ada. Apalagi perkembangan perbankan syariah tidak selaju bank konvensional.

Dengan melihat perkembangan tabungan yang terjadi di Kota Pekanbaru, dapat dilihat bahwa market share tabungan Bank Syariah jumlahnya relatif kecil. Ini berarti Bank Syariah Di Pekanbaru belum maksimal bersaing dengan bank-bank pesaing. Jumlah ini sangat kecil jika dibandingkan dengan share rata-rata untuk setiap kantor cabang bank yang ada di Pekanbaru. Apabila kondisi ini dibiarkan maka lama kelamaan market share tabungan Bank Syariah akan semakin menurun untuk tahun selanjutnya.

Agar perusahaan dapat terus tumbuh dan berkembang dalam persaingan yang semakin tinggi, perusahaan perlu concern terhadap perubahan nasabah melalui faktorfaktor yang dapat dikontrolnya. Minat nasabah merupakan permasalahan yang perlu diperhatikan oleh Bank Syariah di Pekanbaru. Untuk itu diperlukan suatu pemasaran terintegrasi yang sesuai dengan kebutuhan dan harapan setiap nasabah. Dengan memperbaiki hal tersebut diharapkan Bank Syariah dapat menumbuhkan minat menabung bagi nasabahnya dan berujung pada peningkatan profit perusahaan sehingga dapat meraih pangsa pasar yang lebih luas. Adapun tujuan penelitian ini adalah untuk 
menganalisis pengaruh masing-masing dimensi pemasaran terintegrasi (integrated marketing) terhadap minat nasabah untuk menabung pada bank syariah.

\section{TINJAUAN PUSTAKA}

\section{Pemasaran Terintegrasi (Integrated Marketing)}

Pemasaran terintegrasi sebagai satu kesatuan dari bauran pemasaran yang terdiri dari empat $\mathrm{P}$ yaitu Product, Price, Place dan Promotion. Empat $\mathrm{P}$ melambangkan pandangan penjual terhadap perangkap pemasaran yang tersedia untuk mempengaruhi pembeli. Empat $\mathrm{P}$ merupakan formula yang banyak dipergunakan, atau setidaknya merupakan formula dasar untuk bauran pemasaran.

Bauran pemasaran yang terdiri dari 4P yaitu product, price, place, dan promotion, seiiring perkembangan zaman dan tuntutan pasar yang senantiasa mengalami perkembangan telah mengalami evolusi dan terus berkembang searah dengan perkembangan perilaku konsumen dan kecerdasan para ahli pemasaran. Adanya 7P, 8P atau 10P merupakan pengembangan dari 4P. Konsep lain yang merupakan pengembangan dari 4P, yakni SIVA (Solution, Information, Value, Access). Disebut pengembangan dari 4P karena SIVA itu merupakan 4P yang memberikan fokus pada pelanggan.

Perbedaan antara SIVA dan 4P terletak pada penekanan yang diberikan. Bila 4P lebih menekankan pada sisi pasokan produk maka SIVA lebih menekankan pada sisi permintaan/pelanggan dalam manajemen pemasaran. Karena memberikan perhatian pada sisi permintaan/pelanggan itu maka SIVA dinamakan sebagai model manajemen pemasaran yang memfokuskan pada pelanggan atau terpusat pada pelanggan.

Dari sudut pandang pembeli, setiap perangkap pemasaran di rancang untuk memberikan manfaat bagi pelanggan. Keempat dimensi (SIVA) adalah Solution, Information, Value dan Access (Dev \& Schultz, 2005):

1. Solution. Ini terkait dengan seberapa jauh produk tersebut merupakan solusi bagi masalah atau kebutuhan yang dirasakan pelanggan. Misalnya, apakah siaran radio yang kita pancarkan itu menjadi solusi bagi kebutuhan akan pendidikan, hiburan, dan informasi pendengarnya? Solusi ini digambarkan sebagai produk yang sesuai dengan keinginan pelanggan, produk yang sesuai dengan kebutuhan pelanggan, dan produk yang memberikan manfaat bagi pelanggannya atau konsumen.

2. Information. Ini berkaitan dengan pengetahuan pelanggan pada produk yang kita tawarkan. Bila tahu dari mana pengetahuan itu mereka peroleh? Lalu, apakah pengetahuan yang dimilikinya itu mendorong mereka untuk membelinya. Kita bisa ambil misal, banyak pembaca majalah yang memerlukan informasi mengenai hidup sehat. Mereka pun tahu ada tabloid khusus mengenai hidup sehat itu. Tapi kita belum tahu apakah pengetahuan itu mendorong mereka menjadi pembaca dan pembeli setia tabloid tersebut? Informasi ini diperoleh dari media massa, media sosial, atau tim pemasaran perusahaan tersebut.

3. Value. Ini terkait dengan nilai yang dirasakan konsumen. Misalnya, kita bisa menanyakan apakah biaya yang mereka keluarkan sebanding dengan manfaat yang mereka peroleh. Kita bisa kembali dengan siaran radio pada butir 1 tadi. Apakah biaya yang mereka keluarkan dalam bentuk biaya untuk pembayaran listrik dan waktu yang disediakan untuk mendengarkan siaran sebanding dengan manfaat yang mereka peroleh. Makin tinggi manfaat, bisa dikatakan makin bernilai bagi pelanggan. Nilai yang diberikan perusahaan tercermin dari harga/biaya yang sesuai dengan manfaat ekonomis, sesuai dengan manfaat emosional, atau manfaat ekonomis 
sekaligus emosional.

4. Access. Ini berkaitan dengan kemudahan pelanggan untuk mendapatkan produk tersebut sebagai solusi atas kebutuhan dan permasalahan yang mereka hadapi dan alami. Kemudahan akses akan sangat memudahkan pelanggan untuk menyelesaikan permasalahannya. Kita bisa kembali pada contoh tabloid hidup sehat tadi. Bila tabloid itu sangat mudah diperoleh, misalnya dijual di setiap kios penjual koran maka akan membantu memudahkan pelanggan untuk mendapatkannya. Akses dapat dilihat dari kemudahan pelanggan dalam mendapatkan produk, kemudahan dalam pelayanan, dan kemudahan proses pembelian.

Dari perspektif konsumen, solusi merupakan pemecahan masalah bagi konsumen. Informasi penting untuk menjembatani solusi. Nilai dibuat untuk menentukan biaya dan keuntungan. Akses atau bagaimana dapat menemukan paket solusi. Dan pada akhirnya tujuan dari semua pemasaran tegintegrasi itu adalah pembentukan kepuasan dan pembelian ulang dari konsumen. Dua tema kunci dari pemasaran terintegrasi (Dev \& Schultz, 2005) adalah (1) banyak aktivitas pemasaran yang berbeda-beda mengkomunikasikan dan menyampaikan nilai, (2) ketika dikordinasikan, aktivitas pemasaran memaksimalkan efek gabungannya. Dengan kata lain, pemasar harus mendesain dan mengimplementasikan satu aktivitas pemasaran dengan semua aktivitas lainnya.

\section{Minat Nasabah}

Salah satu teori yang dapat menjelaskan mengenai minat adalah teori perilaku terencana (theory of planned behavior) yang dikemukakan oleh Ajzen dalam (Kotler, 2007). Teori perilaku terencana adalah keyakinan-keyakinan yang berpengaruh pada sikap terhadap perilaku tertentu, norma-norma subyektif dan kontrol perilaku yang dihayati. Ketiga komponen ini berinteraksi dan menjadi determinan bagi intensi yang pada gilirannya akan menentukan apakah perilaku yang bersangkutan akan dilakukan atau tidak.

Minat merupakan bagian dari komponen perilaku konsumen dalam sikap mengkonsumsi, kecenderungan responden untuk bertindak sebelum keputusan membeli benar-benar dilaksanakan (Kinnear \& Taylor, 2003). Kecenderungan konsumen untuk membeli suatu merek atau mengambil tindakan berhubungan dengan pembelian yang diukur dengan tingkat kemungkinan konsumen melakukan pembelian (Assael, 2005). Sementara itu minat beli adalah sesuatu yang berhubungan dengan rencana konsumen untuk membeli produk tertentu serta berapa banyak unit produk yang dibutuhkan pada periode tertentu (Howard dalam (Durianto \& Liana, 2004). Dapat dikatakan bahwa minat beli merupakan pernyataan mental dari konsumen yang merefleksikan rencana pembelian sejumlah produk dengan merek tertentu. Hal ini sangat diperlukan oleh para pemasar untuk mengetahui minat konsumen terhadap suatu produk, baik para pemasar maupun ahli ekonomi menggunakan variabel minat untuk memprediksi perilaku konsumen dimasa yang akan datang.

Dalam penelitian ini minat beli merupakan minat nasabah untuk menabung yang diindikasikan melalui minat transaksional, minat referensial, minat preferensial, dan minat eksploratif. Minat transaksional, yaitu kecenderungan seseorang untuk melakukan transaksi maupun membuka rekening baru. Minat refrensial, yaitu kecenderungan seseorang untuk mereferensikan produk kepada orang lain. Minat preferensial, yaitu minat yang menggambarkan perilaku seseorang yang memiliki preferensi utama pada produk tersebut. Preferensi ini hanya dapat diganti jika terjadi sesuatu dengan produk 
prefrensinya. Minat eksploratif, yaitu minat yang menggambarkan perilaku seseorang yang selalu mencari informasi mengenai produk yang diminatinya dan mencari informasi untuk mendukung sifat-sifat positif dari produk tersebut (Ferdinand, 2002).

\section{Kerangka Penelitian dan Hipotesis}

Berdasarkan teori dan jurnal maka disusun kerangka konseptual penelitian sebagai berikut:

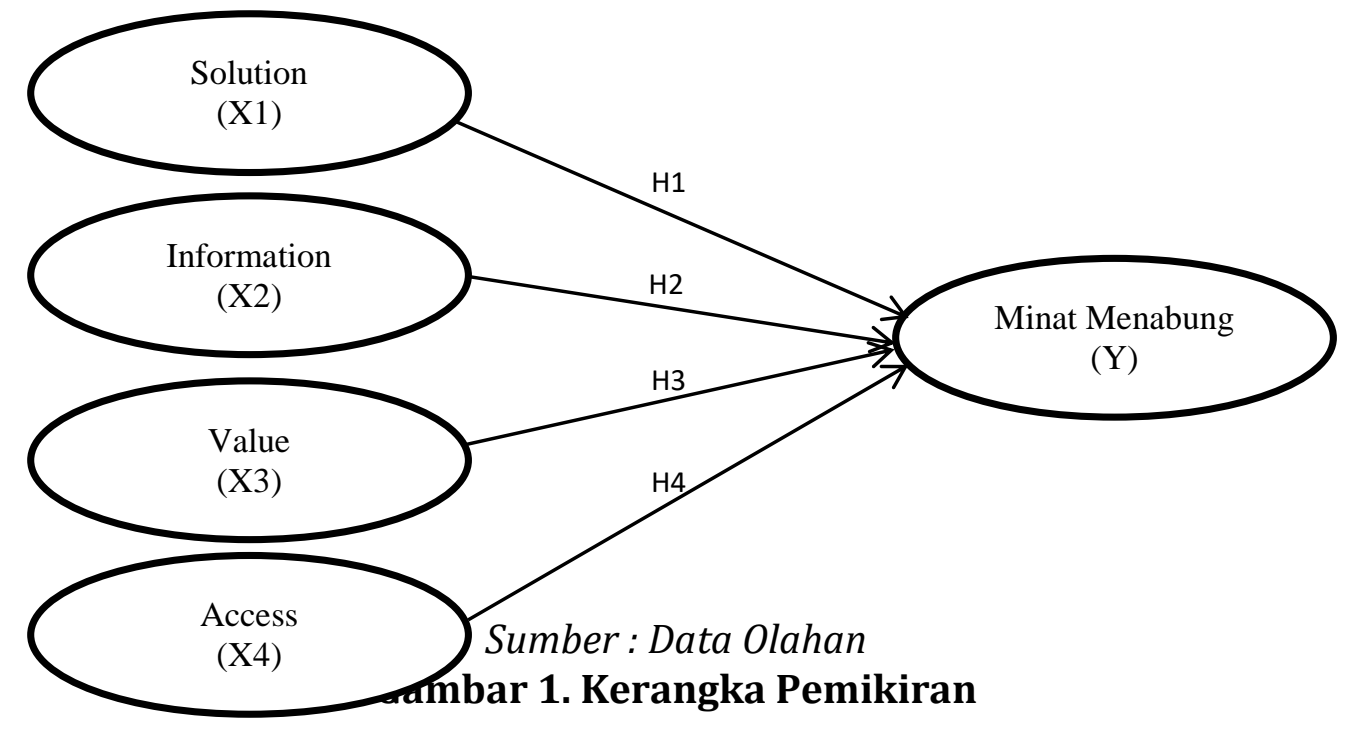

Hipotesis yang diambil dalam penelitian ini adalah sebagai berikut :

H1 : Diduga solution berpengaruh positif dan signifikan terhadap minat menabung.

H 2 : Diduga information berpengaruh positif dan signifikan terhadap minat menabung.

H 3 : Diduga value berpengaruh positif dan signifikan terhadap minat menabung.

H 4 : Diduga access berpengaruh positif dan signifikan terhadap minat menabung.

\section{METODE PENELITIAN}

Penelitian dilakukan secara kuantitatif dengan desain riset kausal dan deskriptif. Desain deskriptif bertujuan untuk menjelaskan sesuatu, seperti menjelaskan karakteristik suatu kelompok yang relevan, mengistimasi persentase unit dalam populasi tertentu yang menunjukkan perilaku tertentu, mengetahui persepsi atas karakteristik produk, mengetahui berapa besar hubungan suatu variabel dan untuk mengetahui prediksi spesifik (Malhotra, 2007). Melalui penelitian ini, peneliti ingin mengetahui seberapa besar hubungan atau pengaruh antara suatu variabel dengan variabel lainnya.

Penelitian kuantitatif yang dilakukan satu kali dalam satu periode (single cross sectional design). Pada jenis riset ini, kegiatan pengumpulan data atau informasi yang didapat dari satu jenis sampel responden untuk satu saat/waktu. Pada penelitian ini dilakukan survei dengan menyebarkan kuesioner, selanjutnya data atau informasi yang diperoleh akan diolah dengan metode statistik menggunakan program AMOS.

Untuk mendukung penelitian yang penulis lakukan, penulis mengumpulkan dua jenis data yang berbeda yaitu data primer merupakan data yang diperoleh langsung dari responden penelitian. Data ini diambil berdasarkan kuesioner yang dibagikan kepada responden atau nasabah tabungan Bank Syariah Di Pekanbaru. Data primer yang diambil 
adalah berupa identitas responden dan penilaian permasalahan yang berkaitan dengan pemasaran terintegrasi dan minat nasabah. Selanjutnya berdasarkan data primer yang telah terkumpul tersebut digunakan sebagai acuan atau dasar dalam melakukan pembahasan dalam penelitian ini. Sedangkan data sekunder merupakan data-data pendukung yang diambil dari literature-literatur atau data perusahaan.

Metode pengumpulan data dimaksudkan untuk memperoleh bahan-bahan yang relevan akurat dan terpercaya teknik pengumpulan data yang digunakan dalam penelitian ini adalah:

\section{a. Survei.}

Suatu teknik pengumpulan informasi yang dilakukan dengan cara menyusun daftar pertanyaan atau kuesioner pada responden.

b. Observasi.

Suatu teknik pengumpulan data yang dilakukan dengan mengadakan penelitian secara langsung di lapangan yaitu melihat, mengamati dan mencatat data.

Operasionalisasi variabel dalam penelitian ini adalah sebagai berikut:

\section{Tabel 1. Operasionalisasi Variabel}

\begin{tabular}{|c|c|c|c|}
\hline Variabel & $\begin{array}{c}\text { Sub } \\
\text { Variabel }\end{array}$ & Definisi Variabel & Indikator \\
\hline \multirow[t]{4}{*}{$\begin{array}{l}\text { Pemasaran } \\
\text { Terintegrasi } \\
\text { (Integrated } \\
\text { Marketing) }\end{array}$} & & $\begin{array}{l}\text { satu kesatuan dari bauran } \\
\text { pemasaran yang } \\
\text { melambangkan rincian } \\
\text { pelangkap aktivitas pemasaran } \\
\text { berpusat pada pelanggan (Dev } \\
\text { \& Schultz, 2005) }\end{array}$ & \\
\hline & $\begin{array}{l}\text { Solution } \\
\text { (X1) }\end{array}$ & $\begin{array}{l}\text { Solusi bagi masalah atau } \\
\text { kebutuhan yang dirasakan } \\
\text { pelanggan }\end{array}$ & $\begin{array}{l}\text { 1. Produk sesuai } \\
\text { dengan keinginan } \\
\text { 2. Produk sesuai } \\
\text { dengan } \\
\text { kebutuhan } \\
\text { 3. Produk } \\
\text { memberikan } \\
\text { manfaat } \\
\text { (Dev \& Schultz, } \\
\text { 2005) }\end{array}$ \\
\hline & $\begin{array}{l}\text { Information } \\
\text { (X2) }\end{array}$ & $\begin{array}{l}\text { Pengetahuan pelanggan pada } \\
\text { produk yang ditawarkan }\end{array}$ & $\begin{array}{l}\text { 1. Informasi media } \\
\text { massa } \\
\text { 2. Informasi sosial } \\
\text { 3. Tim Pemasaran } \\
\text { (Dev \& Schultz, } \\
\text { 2005) }\end{array}$ \\
\hline & $\begin{array}{l}\text { Value } \\
\text { (X3) }\end{array}$ & $\begin{array}{l}\text { Nilai yang dirasakan } \\
\text { konsumen }\end{array}$ & $\begin{array}{l}\text { 1. Harga/biaya } \\
\text { sesuai dengan } \\
\text { manfaat } \\
\text { ekonomis } \\
\text { 2. Harga/biaya } \\
\text { sesuai dengan } \\
\text { manfaat } \\
\text { emosional }\end{array}$ \\
\hline
\end{tabular}




\begin{tabular}{|c|c|c|c|}
\hline Variabel & $\begin{array}{c}\text { Sub } \\
\text { Variabel }\end{array}$ & Definisi Variabel & Indikator \\
\hline & & & $\begin{array}{l}\text { 3. Harga/biaya } \\
\text { sesuai dengan } \\
\text { manfaat } \\
\text { ekonomis } \\
\text { sekaligus } \\
\text { emosional } \\
\text { (Dev \& Schultz, } \\
\text { 2005) }\end{array}$ \\
\hline & $\begin{array}{l}\text { Access } \\
(\mathrm{X} 4)\end{array}$ & $\begin{array}{l}\text { Kemudahan pelanggan untuk } \\
\text { mendapatkan produk } \\
\text { (menabung) }\end{array}$ & $\begin{array}{l}\text { 1. Kemudahan } \\
\text { mendapatkan } \\
\text { produk } \\
\text { 2. Kemudahan } \\
\text { pelayanan } \\
\text { 3. Kemudahan } \\
\text { proses pembelian } \\
\text { (Dev \& Schultz, } \\
\text { 2005) }\end{array}$ \\
\hline $\begin{array}{l}\text { Minat beli } \\
\text { Konsumen } \\
\text { (Minat } \\
\text { Menabung) }\end{array}$ & & $\begin{array}{l}\text { sesuatu yang berhubungan } \\
\text { dengan rencana konsumen } \\
\text { untuk membeli produk } \\
\text { tertentu serta berapa banyak } \\
\text { unit produk yang dibutuhkan } \\
\text { pada periode tertentu } \\
\text { (Howard dalam (Durianto \& } \\
\text { Liana, 2004)) }\end{array}$ & $\begin{array}{l}\text { 1. Minat } \\
\text { transaksional } \\
\text { 2. Minat referensial } \\
\text { 3. Minat } \\
\text { preferensial } \\
\text { 4. Minat eksploratif } \\
\text { (Ferdinand, 2002) }\end{array}$ \\
\hline
\end{tabular}

\section{Sumber : Data Olahan}

Mengingat keterbatasan yang dihadapi, baik waktu, tenaga dan pendanaan, maka peneliti melakukan pembatasan jumlah populasi dengan melakukan sampling. Karena jumlah populasi tidak diketahui secara pasti (non probability), maka pengambilan sampel dilakukan dengan menggunakan Lameshow (Riduwan \& Akdon, 2010) dengan ukuran sampel sebagai berikut:

$$
n=\frac{Z^{2} \cdot P(1-P)}{d^{2}}=\frac{1.96^{2} \times 0.2(1-0.2)}{0.05^{2}}=245,86 \text { (dibulatkan } 246 \text { responden) }
$$

Dimana $\mathrm{n}=$ jumlah sampel

$\mathrm{Z}=$ skor $\mathrm{z}$ pada tingkat kepercayaan $95 \%=1,96$

$\mathrm{P}=$ maksimal estimasi $=0,2$

$\mathrm{d}=$ sampling error $=5 \%(0.05)$

Dengan teknik purposive sampling kriteria responden yang menjadi sampel yaitu yang telah menjadi nasabah Bank Syariah di kota Pekanbaru dan/atau pernah menggunakan/merasakan produk/layanan tabungan Bank Syariah baik secara online maupun offline. Dari 246 kuesioner yang dibagikan, sebanyak 227 eksemplar yang kembali dan terdapat 17 kuesioner yang tidak memenuhi syarat, karena jawaban yang diberikan tidak lengkap dan masalah pada data, sehingga sampel penelitian yang digunakan berjumlah 210 responden. Dalam menganalisis data untuk menguji hipotesis H1 - H4 alat analisis yang dipakai adalah Structural Equation Model (SEM) dari aplikasi AMOS. 


\section{HASIL DAN PEMBAHASAN}

Profil responden dimaksudkan untuk mengetahui komposisi responden yang berpartisipasi dalam penelitian ini khususnya informasi tentang nasabah tabungan pada Bank Syariah di Pekanbaru. Komposisi responden berdasarkan jenis kelamin, usia, pendidikan, pekerjaan, nasabah bank dan lamanya menjadi nasabah.

Tabel 2. Karakteristik Responden

\begin{tabular}{|c|c|c|}
\hline Profil Responden & Frekuensi & $\%$ \\
\hline \multicolumn{3}{|l|}{ Jenis Kelamin } \\
\hline Laki-laki & 156 & 74.3 \\
\hline Perempuan & 54 & 25.7 \\
\hline \multicolumn{3}{|l|}{ Usia } \\
\hline dibawah 21 tahun & 26 & 12.4 \\
\hline 21 tahun sampai dengan 30 tahun & 112 & 53.3 \\
\hline 31 tahun sampai dengan 40 tahun & 45 & 21.4 \\
\hline 41 tahun sampai dengan 50 tahun & 26 & 12.4 \\
\hline diatas 50 tahun & 1 & 0.5 \\
\hline \multicolumn{3}{|l|}{ Pendidikan } \\
\hline SMA Sederajat & 142 & 67.6 \\
\hline Akademi/Diploma & 17 & 8.1 \\
\hline Sarjana & 48 & 22.9 \\
\hline Pasca Sarjana & 3 & 1.4 \\
\hline \multicolumn{3}{|l|}{ Pekerjaan } \\
\hline Pelajar/Mahasiswa & 42 & 20.0 \\
\hline Wiraswasta & 39 & 18.6 \\
\hline Karyawan/Pegawai & 101 & 48.1 \\
\hline Profesional & 10 & 4.8 \\
\hline Ibu Rumah Tangga & 18 & 8.6 \\
\hline \multicolumn{3}{|l|}{ Nasabah Bank } \\
\hline Bank Syariah Mandiri & 78 & 37.1 \\
\hline Bank Muamalat & 55 & 26.1 \\
\hline BNI Syariah & 35 & 16.6 \\
\hline BRI Syariah & 42 & 20.2 \\
\hline \multicolumn{3}{|l|}{ Lama Menjadi Nasabah } \\
\hline Dibawah 1 tahun & 39 & 18.6 \\
\hline 1 tahun sampai dengan 3 tahun & 70 & 33.3 \\
\hline 3 tahun sampai dengan 5 tahun & 39 & 18.6 \\
\hline Lebih dari 5 tahun & 62 & 29.5 \\
\hline
\end{tabular}

Sumber : Hasil Olahan Data

\section{Analisis Model Pengukuran (Measurement Model)}

Variabel-variabel laten atau konstruk yang digunakan pada model penelitian ini terdiri dari 5 variabel laten dengan jumlah indikator variabel eksogen masing-masing 3 indikator dan jumlah indikator variabel endogen sebanyak 4 indikator. Jadi total indikator sebanyak 16 indikator. Karena apabila analisis faktor konfirmatori per variabel tidak memberikan hasil yang jelas untuk variabel laten, maka pengujian confirmatory factor analysis akan dilakukan dengan mempertimbangkan kelompok variabel eksogen dan kelompok variabel endogen. 
Indikator atau variabel teramati yang dapat diterima adalah yang tidak memiliki nilai negative error variance dan standardized loading factors lebih besar atau sama dengan 0,5 (Igrabia et.al,1997 dalam (Akbar, 2014). Hasil ini menunjukkan bahwa indikator dalam penelitian ini telah memenuhi syarat yang baik (valid dan reliabel). Dengan tidak adanya offending estimate, maka pengujian selanjutnya dapat dilakukan.

\section{Analisis Faktor Konfirmatory Konstruk Eksogen}

Model pengukuran untuk analisis faktor konfirmatori konstruk eksogen yaitu pengukuran terhadap dimensi-dimensi yang membentuk variabel/konstruk laten independen atau variabel eksogen dalam model penelitian, yaitu Solution (X1), Information (X2), Value (X3), Access (X4) yang masing-masing memiliki 3 indikator. Unidimensionalitas dari dimensi ini diuji melalui analisis faktor konfirmatori konstruk eksogen.

Dari hasil pengolahan, nilai loading factor (std estimate) dianggap menunjukkan hasil yang baik sebagai pembentuk masing-masing variabel laten apabila bernilai lebih besar dari 0,5. Confirmatory Factor Analysis (CFA) Konstruk Eksogen adalah sebagai berikut:

Tabel 3. Hasil Analisis Faktor Konfirmatory Konstruk Eksogen

\begin{tabular}{llc}
\hline & Standardized Regression Weights & Estimate \\
\hline X13 <--- & Solution & 0,769 \\
X12 <--- & Solution & 0,830 \\
X11 <--- & Solution & 0,771 \\
X23 <--- Information & 0,788 \\
X22 <--- Information & 0,816 \\
X21 <--- Information & 0,673 \\
X33 <--- Value & 0,661 \\
X32 <--- Value & 0,991 \\
X31 <--- Value & 0,500 \\
X43 <--- Access & 0,866 \\
X42 <--- Access & 0,767 \\
X41 <--- Access & 0,771 \\
\hline
\end{tabular}

Sumber : Hasil Olahan Data

Dengan hasil ini, maka terdapat indikator pembentuk variabel laten konstrukkontruk eksogen yang menunjukkan sebagai indikator yang lemah dalam pengukuran variabel laten dan tidak dapat menggambarkan kontribusinya terhadap pembentukan variabel penelitian sehingga variabel teramati/indikator yang perlu dihilangkan (tidak ikut diestimasi). Indikator yang dibuang/didrop tersebut ialah X3.1 yang merupakan indikator dari variabel Value. Selanjutnya berdasarkan analisis faktor konfirmatori ini, maka model penelitian dapat digunakan untuk analisis selanjutnya dengan melakukan penyesuaian model

\section{Analisis Faktor Konfirmatory Konstruk Endogen}

Model pengukuran untuk analisis faktor konfirmatori konstruk endogen yaitu pengukuran terhadap dimensi-dimensi yang membentuk variabel laten/konstruk laten 
dependen atau variabel endogen dalam model penelitian. Variabel-variabel/konstruk laten endogen dalam model penelitian ini terdiri dari 1 variabel laten yaitu Minat Nasabah dengan memiliki 4 observed variable.

Dari hasil pengolahan terlihat bahwa semua nilai loading factor (std estimate) untuk masing-masing indikator pada variabel endogen lebih besar dari 0,5. Confirmatory Factor Analysis (CFA) Konstruk Endogen adalah sebagai berikut:

Tabel 4. Hasil Analisis Faktor Konfirmatory Konstruk Endogen

\begin{tabular}{llc}
\hline & Standardized Regression Weights & Estimate \\
\hline Y4 <--- & Minat & 0,832 \\
Y3 <--- & Minat & 0,567 \\
Y2 <--- & Minat & 0,718 \\
Y1 <--- & Minat & 0,692 \\
\hline
\end{tabular}

Sumber : Hasil Olahan Data

Dengan hasil ini, maka dapat dikatakan bahwa indikator-indikator pembentuk variabel laten konstruk-kontruk endogen telah menunjukkan sebagai indikator yang kuat dalam pengukuran variabel laten dan dapat menggambarkan kontribusinya terhadap pembentukan variabel penelitian sehingga tidak ada variabel teramati/indikator yang perlu dihilangkan. Selanjutnya berdasarkan analisis faktor konfirmatori ini, maka model penelitian dapat digunakan untuk analisis selanjutnya tanpa modifikasi atau penyesuaian.

\section{Analisis Model Struktural (Structural Model)}

Analisis selanjutnya adalah analisis model struktural secara full model. Model struktural adalah model yang dibangun oleh hubungan antar variabel laten/konstruk yang indikator-indikatornya telah diuji dengan dilakukan analisis terhadap tingkat validitas dari indikator-indikator pembentuk variabel laten yang diuji dengan confirmatory factor analysis. Analisis hasil pengolahan data pada tahap full model SEM dilakukan dengan melakukan uji kesesuaian dan uji statistik.

Dari model struktural yang diperoleh dari output AMOS, masih terdapat nilai hasil kesesuaian model dari konstruk eksogen yang dibangun belum memenuhi kriteria indeks pengujian kelayakan (goodness of fit). Oleh karena itu perlu dilakukan modifikasi model dengan cara merespesifikasi model dengan membuat covarian antar indikator yang memiliki nilai Modification Indicies (M.I) yang besar. Namun sebelum model diterima, perlu dilakukan uji kesesuaian model.

\section{Uji Kesesuaian Model (Goodness Of Fit)}

Uji kesesuaian model bertujuan untuk mengukur derajat kesesuaian hasil estimasi model dengan matrik data input penelitian. Pengujian ini akan mengevaluasi apakah model yang dihasilkan merupakan model fit atau tidak. Merujuk pada prinsip parsimony dalam (Haryono \& Parwoto, 2013), maka jika terdapat satu atau dua kriteria goodness of fit yang telah memenuhi, model dikatakan baik, sehingga model dapat digunakan untuk pengujian hipotesis. Hasil pengujian kesesuaian model dapat dilihat pada tabel berikut ini:

\section{Tabel 5. Hasil Uji Kesesuaian Model}




\begin{tabular}{lcc}
\hline $\begin{array}{c}\text { Goodness of Fit } \\
\text { Index }\end{array}$ & Hasil Estimasi & $\begin{array}{c}\text { Tingkat } \\
\text { Kecocokan }\end{array}$ \\
\hline Chi-square & 172.938 & Poor Fit \\
Probability & 0.000 & Poor Fit \\
RMSEA & 0.104 & Poor Fit \\
CFI & 0.928 & Good Fit \\
TLI & 0.857 & Marginal Fit \\
NFI & 0.902 & Good Fit \\
IFI & 0.930 & Good Fit \\
CMIN/DF & 3.263 & Poor Fit \\
\hline
\end{tabular}

Sumber : Hasil Olahan Data

Dari uji kecocokan keseluruhan model, terdapat beberapa nilai yang tidak fit dan marginal fit menurut kriterianya. Namun secara hasil keseluruhan model yang dibangun telah memenuhi kriteria indeks pengujian kelayakan (good fit). Jadi pengujian ini menghasilkan konfirmasi yang baik atas dimensi-dimensi faktor serta hubunganhubungan kausalitas antar faktor.

Dari model struktural yang diperoleh dari output AMOS, menunjukkan pengaruh antara variabel laten yang satu dengan yang lainnya dengan melihat nilai-t (Critical Ratio) dan probability $(P)$. Ketika Critical Ratio $(C R) \geq 1.96$ dan nilai p dibawah 0,05 maka variabel laten tersebut memberikan pengaruh yang signifikan terhadap variabel laten lainnya. Sebaliknya, ketika Critical Ratio $(C R)<1.96$ dan nilai p diatas 0,05 maka variabel laten tersebut tidak memberikan pengaruh yang signifikan terhadap variabel laten lainnya (Akbar, 2014). Hasil pengujian hipotesis adalah sebagai berikut:

Tabel 6. Hasil Pengujian Hipotesis

\begin{tabular}{llrrrrl}
\hline & Estimate & S.E. & C.R. & P & Hipotesis \\
\hline Minat $<---$ & Value & .637 & .085 & 7.514 & $* * *$ & Diterima \\
Minat $<---$ & Information & .583 & .137 & 4.250 & $* * *$ & Diterima \\
Minat $<---$ & Solution & .424 & .069 & 6.181 & $* * *$ & Diterima \\
Minat $<---$ & Access & .270 & .071 & 3.779 & $* * *$ & Diterima \\
\hline
\end{tabular}

Sumber : Hasil Olahan Data

Berdasarkan tabel di atas, nilai t pada model struktural, dapat diidentifikasi bahwa seluruh lintasan memiliki pengaruh positif dan signifikan karena memiliki Critical Ratio $(C R) \geq 1.96 /$ Probability $(P) \leq 0,05$ sehingga seluruh hipotesis diterima.

\section{Pembahasan Hasil Penelitian \\ Pengaruh Solution terhadap Minat Nasabah}

Berdasarkan hasil pengujian hipotesis tentang pengaruh solution terhadap minat masyarakat untuk menabung pada bank syariah, secara empiris membuktikan bahwa solution memberikan pengaruh langsung yang positif dan signifikan terhadap minat masyarakat dalam menabung pada bank syariah. Berpengaruh positif artinya semakin banyak solusi yang diberikan bank syariah melalui kelebihan dan keunggulan produk tabungannya maka akan dapat meningkatkan minat masyarakat untuk menabung pada bank syariah. Demikian juga sebaliknya, apabila sedikit maka akan berimbas terhadap 
turunnya minat masyarakat untuk menabung pada bank syariah. Signifikansi dari hasil penelitian dapat diartikan bahwa munculnya minat masyarakat untuk menabung pada bank syariah tergantung pada banyaknya solusi yang diberikan bank syariah melalui fitur produk tabungannya.

Dari hasil analisis deskriptif, rata-rata jawaban responden berada dalam rentang yang cukup positif (setuju). Hal ini menunjukkan bahwa produk tabungan bank syariah secara umum telah memberikan solusi dalam memenuhi kebutuhan dan keinginan nasabah dari masyarakat Pekanbaru. Meskipun demikian, bank perlu memberikan perhatian terhadap variabel ini terutama pada indikator produk yang memberikan manfaat, karena cukup banyak responden yang memberikan persepsi yang cukup rendah. Artinya bank syariah masih belum optimal dalam memberikan manfaat yang lebih dari produk motor yang diproduksinya. Sedangkan analisis koefisien jalur dalam SEM, menunjukkan bahwa nilai loading factor dari variabel Solution dengan kontribusi sebesar 42.4\%. Hasil ini sesuai dengan nilai deskripsi tanggapan responden. Ini berarti bank syariah harus membuat produk tabungan yang dapat memberikan solusi bagi masyarakat yaitu yang sesuai dengan keinginan dan kebutuhan serta memberikan manfaat lebih bagi masyarakat.

\section{Pengaruh Information terhadap Minat Nasabah}

Hasil penelitian secara empiris membuktikan bahwa information berpengaruh positif dan signifikan terhadap minat masyarakat pada produk tabungan Bank syariah. Ini berarti bahwa semakin banyak informasi yang diberikan bank kepada masyarakat, maka semakin tinggi minat masyarakat sebagai calon nasabah untuk melakukan transaksi pada bank tersebut. Sedangkan jika informasi yang diberikan sedikit maka minat masyarakat juga akan menurun. Informasi yang diberikan perusahaan ini dilihat dari informasi melalui media massa, media sosial atau tim pemasaran.

Rata-rata jawaban responden dalam deskripsi variabel berada dalam rentang yang cukup positif oleh responden. Namun masih terdapat responden yang memberikan persepsi yang rendah yaitu pada indikator tim pemasaran. Hal ini menunjukkan bahwa informasi melalui media massa, media sosial dan tim sales menjadi alasan bagi masyarakat untuk memilih produk tabungan. Namun tim pemasaran Bank syariah saat ini yang ada di Pekanbaru masih dianggap belum memberikan banyak informasi bagi masyarakat dalam memberikan pengetahuan nasabah terhadap produk tabungan yang ditawarkan. Hal ini terlihat dari masih adanya responden yang memberikan persepsi yang rendah indikator tersebut. Sedangkan dari analisis koefisien jalur dalam SEM, menunjukkan bahwa nilai loading factor dari variabel Information dengan kontribusi sebesar 58,3\%. Oleh karena itu, tim pemasaran bank syariah diberikan training khusus tentang product knowledge sehingga setiap calon customer yang dijumpainya akan lebih paham dengan produk bank syariah.

\section{Pengaruh Value terhadap Minat Nasabah}

Pada hasil penelitian ini juga dilakukan pengujian hipotesis tentang bagaimana pengaruh value yang diperoleh nasabah terhadap minat menabung. Berdasarkan hasil analisis dan pengujian yang telah dilakukan mengenai pengaruh antara value terhadap minat nasabah, maka dapat disimpulkan bahwa value berpengaruh positif dan signifikan terhadap minat. Hal ini berarti semakin banyak value yang diterima nasabah maka minat nasabah untuk menabung juga semakin meningkat. Begitu juga sebaliknya, semakin rendah value yang diterima maka minat menabung juga akan semakin menurun. 
Sedangkan jika dilihat dari hasil analisis deskriptif, rata-rata jawaban responden belum berada dalam rentang yang cukup tinggi. Hal ini dapat dilihat dari banyaknya responden yang memberikan respon negatif pada indikator nilai yang sesuai dengan manfaat emosional. Value ini dilihat dari nilai sesuai dengan manfaat ekonomi, nilai yang sesuai dengan manfaat emosional dan manfaat ekonomis sekaligus emosional. Dari analisis koefisien jalur dalam SEM, menunjukkan bahwa nilai loading factor dari variabel Value dengan kontribusi sebesar $63,7 \%$. Nilai ini menunjukkan nilai terbesar daripada variabel lainnya. Hal ini menunjukkan bahwa bank syariah harus menciptakan nilai bagi nasabah dengan memberikan manfaat ekonomis dan emosional.

\section{Pengaruh Access terhadap Minat Nasabah}

Kemudian pembahasan selanjutnya adalah mengetahui bagaimana pengaruh access terhadap minat nasabah. Berdasarkan analisis dan pengujian yang telah dilakukan maka didapatkan hasil penelitian bahwa access memiliki pengaruh yang positif dan signifikan terhadap minat untuk menabung. Ini berarti bahwa semakin dekat akses dengan nasabah dan pasar maka akan dapat meningkatkan minat masyarakat untuk menabung. Jika akses penyampaian produk jauh dari masyarakat maka akan menurunkan minat nasabah.

Hasil analisis deskriptif menunjukkan rata-rata jawaban responden berada dalam rentang yang cukup tinggi. Ini dapat diartikan bahwa akses yang diberikan perusahaan Bank syariah saat ini di kota Pekanbaru melalui kemudahan mendapatkan produk, pelayanan dan proses pembelian sudah cukup baik. Namun masih ada beberapa responden yang memberikan respon yang rendah terutama pada indikator kemudahan pelayanan. Sedangkan dari analisis koefisien jalur dalam SEM, menunjukkan bahwa nilai loading factor dari variabel Access dengan kontribusi sebesar $27 \%$. Nilai ini menunjukkan bahwa bank syariah harus menyediakan akses yang dekat dengan masyarakat dan pasar dengan memberikan kemudahan dalam mendapatkan produk, pelayanan dan proses transaksi.

\section{PENUTUP}

Penelitian ini dilatarbelakangi pada pentingnya memperoleh keunggulan kompetitif dalam perbankan sehingga perusahaan memperoleh pangsa pasar yang lebih luas. Hal ini didasari pada perubahan lingkungan persaingan yang ketat yang memaksa perusahaan perbankan dalam upaya pemasarannya untuk menjaring nasabah yang lebih banyak. Penelitian ini merupakan pengembangan model yang lebih komprehensif dengan melakukan integrasi atas berbagai penelitian terdahulu yang telah dilakukan sebelumnya. Hasil pengujian atas integrasi model ini menunjukkan bahwa adanya interaksi beberapa faktor-faktor yang mempengaruhi minat nasabah untuk menabung di bank syariah. Hasil penelitian membuktikan bahwa semua dimensi pemasaran terintegrasi dapat menumbuhkan minat bagi nasabah untuk menabung pada bank syariah yang ada di Pekanbaru.

Produk tabungan yang memiliki fitur yang sesuai dengan keinginan dan kebutuhan serta memberikan manfaat bagi penabung, dapat menarik minat nasabah untuk menabung pada bank syariah. Berbagai sarana informasi yang dilakukan oleh bank akan dapat memberikan minat bagi masyarakat untuk dapat mempertimbangkan bank syariah sebagai salah satu tempat berinvestasi ataupun menyimpan uang/dana. Nilai yang sesuai dengan manfaat yang diperoleh nasabah menjadi alasan bagi nasabah untuk memilih bank. Kemudahan nasabah dalam bertransaksi sangat berperan penting dalam meningkatkan minat masyarakat untuk menabung pada bank syariah. Oleh karena itu 
minat nasabah akan tercipta apabila akses bank dekat dengan konsumen dan pasar. Kemampuan bank syariah dalam meningkatkan dimensi pemasaran terintegrasi secara keseluruhan merupakan aspek yang krusial untuk menjadikan masyarakat sebagai nasabahnya.

Penelitian ini tidak terlepas dari berbagai keterbatasan, sehingga hasil penelitian ini juga hanya dapat dimaknai dalam lingkup yang terbatas. Data sampel difokuskan untuk masyarakat atau nasabah yang memiliki rekening tabungan pada bank syariah. Sehingga tidak berlaku umum pada bank konvensional dan produk lainnya selain tabungan. Lingkup penelitian juga dibatasi untuk wilayah kota Pekanbaru. Hal ini menyebabkan hasil penelitian ini hanya dapat diaplikasikan untuk daerah Pekanbaru dan belum tentu berlaku hal yang sama untuk di luar wilayah tersebut. Untuk penelitian selanjutnya mungkin dapat menggunakan alat analisis dan variabel lainnya. Dengan keterbatasan-keterbatasan tersebut menyebabkan penelitian ini tidak digeneralisir untuk konteks diluar batasan, sehingga dapat menjadi bahasan untuk peneliti yang akan datang.

\section{DAFTAR RUJUKAN}

Agustin, R. D., Kumadji, S., \& Yulianto, E. (2015). Pengaruh Integrated Marketing Terhadap Minat Beli Serta Dampaknya Pada Keputusan Pembelian (Survei Pada Konsumen Non-Member Tupperware Di Kota Malang). Jurnal Administrasi Bisnis (JAB) Vol.22 No.2, 2-11.

Akbar, Y. R. (2014). Mengapa Menggunakan SEM. Retrieved 2019, from The Yy Blog: www.yrasemsi.blogspot.com

Antonio, S. (2007). Bank Syariah dari Teori ke Praktik. Jakarta: Gema Insani.

Assael, H. (2005). Customer Behavior and Marketing Action. Boston: Wadsworth Inc.

Dev, C. S., \& Schultz, D. E. (2005). Get Results With The New Marketing Mix. New York: American Marketing Association.

Durianto, D., \& Liana. (2004). Strategi Menaklukkan Pasar Melalui Riset Ekuitas dan Perilaku Merek. Jakarta: PT. Gramedia Pustaka Utama.

Ferdinand, A. (2002). Manajemen Pemasaran: Sebuah Pendekatan Strategik. Semarang: Research Paper Series. BP. UNDIP.

Haryono, S., \& Parwoto, W. (2013). Structural Equation Modeling untuk Penelitian Manajemen. Bekasi, Jawa Barat: PT. Intermedia Personalia Utama.

Kinnear, T. C., \& Taylor, J. (2003). Riset Pemasaran (Terjemahan oleh Thamrin) Edisi Tiga. Jakarta: Erlangga.

Kotler, P. (2007). Marketing Management. New Jersey: Prentice Hall Inc Publishing.

Kotler, P., \& Keller, K. L. (2012). Marketing Management. New Jersey: Pearson Education, Inc publishing as Prentice Hall.

Malhotra, N. K. (2007). Riset Pemasaran, Pendekatan Terapan Edisi Ke empat. Jakarta: Penerbit Indeks.

Ningwulan, E. P., Widyastuti, S., \& Derriawan. (2017). Strategi Pengembangan Minat Pembelian Melalui Peningkatan Kepercayaan Nasabah BCA. Jurnal Ekobisman Vol.2 No.2, 167-184.

Riduwan, \& Akdon. (2010). Analisis Jalur dan Aplikasi Statistik Penelitian. Bandung: Alfabeta.

Situmorang, Y. L., \& Ferdinand, A. T. (2017). Analisis Faktor-Faktor Yang Mempengaruhi Keputusan Pembelian Sepeda Motor Yamaha (Studi Pada Dealer Yamaha PT. 
Utama Megah Sentosa Bersaudara). Diponegoro Journal of Management Vol.6 No.3, $1-14$.

Srivastava, T. S., \& Ho, C. K. (2006). The Trident Model For Customer Centric Enterprise System At Comfort Transportation, Singapore. MIS Quarterly Executive Vol. 5 No.3, 109-124.

Yusri. (2017). Pertumbuhan Pasar Perbankan Syariah di Riau. Retrieved 2019, from wartariau: www.wartariau.com

Zeithaml, V. A., \& Bitner, M. (2000). Service Marketing: Integrating Customer Focus Across The Firm 3rd Edition. New York: The Mc Graw-Hill Companies, Inc. 